\title{
Biogas and Electrical Energy Production from Market Waste at Fixed Dome Bio-digester in Talang Banjar Jambi
}

\author{
Leila Kalsum ${ }^{1, *}$ Yordan Hasan $^{2}$, Rusdianasari, Rusdianasari ${ }^{1}$, Aida Syarif ${ }^{1}$, \\ Dayaningrat Dayaningrat ${ }^{1}$, Syaiful $\mathrm{M}^{1}$
}

\author{
${ }^{1}$ Renewable Energy Study Program, Sriwijaya State Polytechnic, Palembang Indonesia \\ ${ }^{2}$ Electronic Engineering Sriwijaya State Polytechnic, Palembang Indonesia \\ *Corresponding author. Email: leila_k@polsri.ac.id
}

\begin{abstract}
The waste problem commonly is almost the same in every big city. When it is not managed properly, it will be piled up very quickly. The city of Jambi produces approximately 1,838.48 m3/day of waste. Organic waste originating from market waste in Jambi City is dominated by vegetable waste, so that its organic content can be converted into biogas energy. This abundant of waste is managed in Talang Banjar in Jambi City which is to be converted into biogas in order to reduce environmental pollution and also convert organic waste into useful materials what it is so called biogas that can be used by the community. This waste treatment used a fixed-dome type bio-digester. The purpose of the study was to analyze the production of biogas and electrical energy generated from waste processing at a fixed-dome bio-digester in Talang Banjar Jambi. Based on the results of the study, it found out that the average methane gas content produced was above $60 \%$ with an average biogas volume of $5 \mathrm{~m}^{3} /$ hour, and the electrical energy produced $58.5 \mathrm{kWh} / \mathrm{hour}$.
\end{abstract}

Keywords: Organic waste, fixed dome digester, biogas, electrical energy

\section{INTRODUCTION}

Based on Law No. 18 of 2008 that waste is part of something that is useless, disliked or something that must be thrown away, which is generally solid material. Regarding to its nature, waste is divided into organic waste and inorganic waste. Organic waste is easily decomposed such as food scraps, vegetables, dry leaves, and so on. It can be further processed into compost. Meanwhile, inorganic waste is waste that cannot be decomposed easily, such as plastic food packaging containers, paper, plastic toys, bottles and drinking glasses, cans and so on.

The City of Jambi, like other big cities, produces $1,838.48 \mathrm{~m} 3 /$ day of waste. The characteristics of waste from this place are dominated by market waste in the form of inorganic waste, average amount of $67.02 \%$ and organic waste by $32.98 \%$ [1]. This organic waste is processed in Talang Banjar in Jambi City using an anaerobic digestion system. Anaerobic digestion is a process of decomposition of biodegradable materials under controlled conditions without oxygen and at temperatures suitable for meshophilic or thermophilic or facultative bacterial species to be converted into biogas and digestate products [2]. The most widely used anaerobic digestion technologies are Fixed dome digester, Floating drum digester, and Tubular digester. Fixed dome type anaerobic digestion technology is the type used in this study to treat market waste in Talang Banjar Jambi City. There are 4 anaerobic digestion reactors with a volume of $30 \mathrm{~m}^{3}$. The total processing capacity is 1 ton/day. 
The fixed-dome digester design was first developed in China in 1936, and then widely developed around the world with 6 volumes, 8 , and $10 \mathrm{~m}^{3}[3,4,5]$. The digester design consists of an underground digester section with a dome-shaped lid made of brick, stone or concrete. Another part is the slurry reservoir which is open to atmospheric pressure. The gas produced in the digester accumulates in the dome of the digester. The pressure from the biogas that is formed will press the slurry into the slurry reservoir. Examples of fixeddome digesters are the Chinese fixed-dome digester and Indian-fixed dome (Deenbandu, Nepalese fixed dome (GGC-2047), etc. [6]. The Chinese fixed-dome digester can be seen in Figure 1. below:

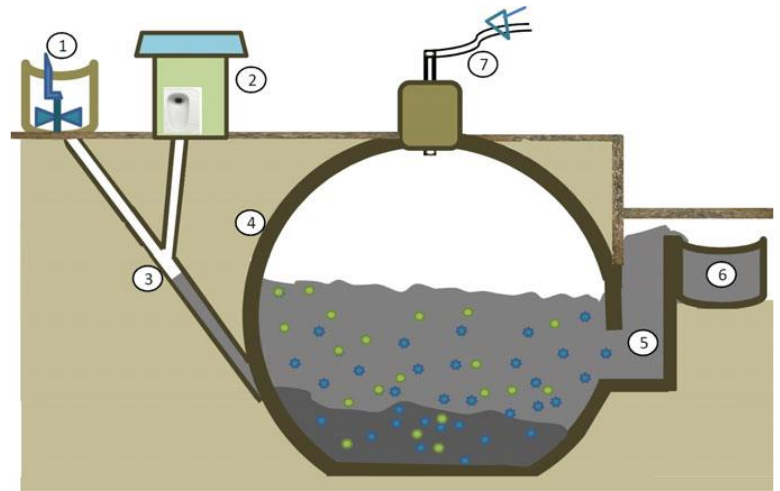

Figure 1 Chinese fixed-dome digester [6]

Based on working principle of the biodigester, organic waste or waste after being mixed with water in a certain ratio, in general such a 1:1 or 1:2 ratio is used and then the mixture is put into the biodigester. The effective volume of the biodigester is $80 \%$ filled with slurry and $20 \%$ is used for biogas to be produced from the anaerobic digestion process [7]. The working principle of a fixed-dome digester in general can be seen in Figure 2 below:

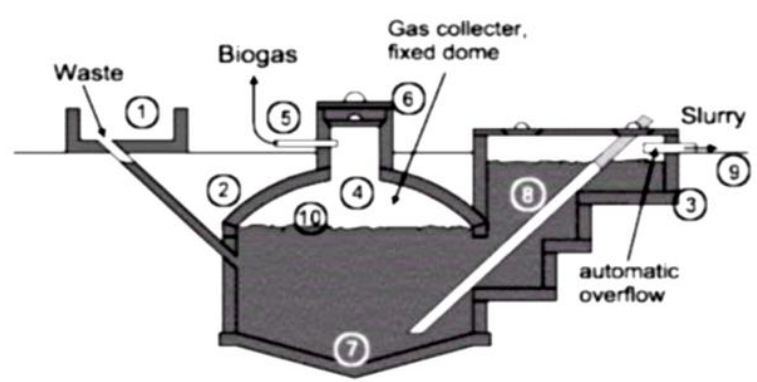

Figure 2 Working Principles of Fixed Dome Biodigester [7]

\section{MATERIALS AND METHODS}

\subsection{Materials}

The raw material for biogas production in this study was market organic waste which was dominated by cabbage and pineapple which were not suitable for consumption from the Talang Banjar market, Jambi City. While the equipment used was 1 unit of biogas processing owned by Talang Banjar Jambi City which consisted of 4 inlet tanks, 4 fixed dome digesters, gas bags, multi meter and biogas analyzer.

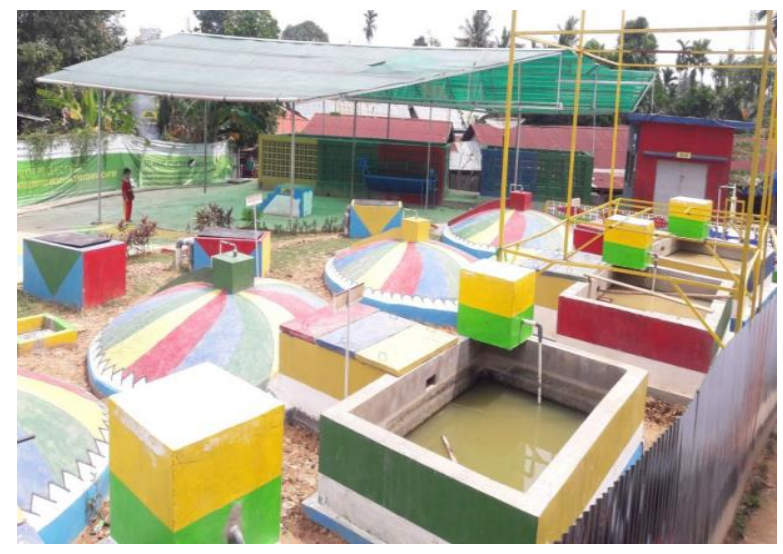

Figure 3 Biogas unit in Talang Banjar Jambi

\subsection{Methods}

The procedures for making biogas in Talang Banjar Jambi as follows:

1. First of all, organic waste such as cabbage and pineapples taken from the Talang Banjar market were sorted by separating plastic or other impurities. Then the organic wastes were chopped using a chopper machine;

2. After chopping the wastes were put into the inlet tub with the ratio between the chopped waste and water was 1: 1 ;

3. Then, it was stirred manually with long bamboo;

4. Each inlet tank was filled with mixed organic waste with a 7-day interval of filling, after that routinely in 1 week 3 times filling; on Tuesday, Thursday, and Saturday. Each inlet tub was connected to the digester.

5. The anaerobic digestion process will occur in the digester and produce biogas.

6. Biogas was then channeled and collected in storage bags/balloons.

7. Sampling of biogas was taken using a biogas sample bag or tedlar bag and brought to the laboratory for analysis its content. 


\subsection{Biogas analysis}

Biogas analysis was carried out by first measuring the $\mathrm{CH}_{4}$ content of biogas using a bosean gas analyzer. Furthermore, the volume of gas produced from the fixed dome digester unit was measured for 4 weeks. The results of the biogas volume data were then converted to energy using a source [8] where $1 \mathrm{~m} 3$ of biogas was equivalent to $11.17 \mathrm{kWh}$ of electricity.

\section{RESULTS AND DISCUSSION}

\subsection{Concentration of methane gas from biogas}

The results from measuring the quality of biogas, especially for the concentration of methane gas produced from the anaerobic digestion process at the Fixe Dome Digester in Talang Banjar, Jambi City, are shown in Table 1. below:

Tabel 1. Results of measuring the quality of $\mathrm{CH}_{4}$

\begin{tabular}{cc}
\hline Samples & Methane $\left(\mathrm{CH}_{4}\right)$ \\
\hline 1 & $68 \%$ \\
2 & $64 \%$ \\
3 & $64 \%$ \\
4 & $69 \%$ \\
5 & $66 \%$ \\
\hline
\end{tabular}

Based on the data from the biogas test results in Table 1 above, in the test using a portable gas analyser on the first sample that the methane gas content was $68 \%$, the second test decreased methane gas content by $64 \%$, in the 3 rd test the methane gas content was stable by $64 \%$, in the 4 th test the methane gas content increased by $69 \%$, and in the 5 th test was a $66 \%$ decreasing in methane gas content. In conclusion that the average methane gas content produced was above $60 \%$. Meanwhile, from the same study used organic materials as materials for biogas production, methane gas was produced [9] in his research, the levels of methane gas using organic waste materials were $68.5 \%$ and the smallest was $67.75 \%$. While in research [10] the content of methane gas using organic waste from the market was $52.8 \%$. Thus the results of the biogas produced were line with theory [11] says the composition of biogas for methane $\left(\mathrm{CH}^{4}\right)$ gas with a concentration range of $50-70 \%$.

The biogas produced in the fixed dome digester in Talang Banjar Jambi City can be used directly by the surrounding community for biogas stoves and lighting lamps in the Talang Banjar market using biogas generator. In the equivalence according to [12] for $1 \mathrm{~m}^{3}$ of biogas equals to $0.46 \mathrm{~kg}$ of LPG, 0.62 liters of kerosene, $0.8 \mathrm{~L}$ gasoline, $2.5 \mathrm{~kg}$ of firewood and 0.52 diesel oil.

\subsection{Volume and Electrical Energy of Biogas}

From the results of measuring the volume of biogas formed during observations in April 2021, the following are the results of the average measurement of the volume of biogas obtained.

Table 2. Biogas volume

\begin{tabular}{cc}
\hline Week & $\begin{array}{c}\text { Average Biogas Volume } \\
\left(\mathrm{m}^{3} / \text { hour }\right)\end{array}$ \\
\hline I & 4,3 \\
II & 4,5 \\
III & 5,6 \\
IV & 5,6 \\
\hline
\end{tabular}

Based on the data in Table 2. The volume of biogas produced in the fixed dome digester of Talang Banjar Jambi, in the first week of April, the average biogas volume was $4.3 \mathrm{~m}^{3}$, for the second week of April, the average biogas volume was $4.5 . \mathrm{m}^{3}$, then in the third week of April, the average biogas volume was $5.6 \mathrm{~m}^{3}$ and at the end of the month or at fourth week, the biogas volume was $5.6 \mathrm{~m}^{3}$. So that, the average biogas production for four weeks was $5 \mathrm{~m}^{3}$

From the biogas volume data obtained for 4 weeks of measurement, it can be calculated the amount of electrical energy produced. The following table 3 is the result of the conversion of biogas volume to electrical energy.

Table 3. Electrical Energy from Biogas $\left(1 \mathrm{~m}^{3}\right.$ equals to 11.17 Kwh)

\begin{tabular}{ccc}
\hline Week & $\begin{array}{c}\text { Biogas Volume } \\
\left(\mathrm{m}^{3}\right)\end{array}$ & $\begin{array}{c}\text { Electric energy } \\
(\mathrm{Kwh})\end{array}$ \\
\hline & & \\
I & 4,3 & 50,31 \\
II & 4,5 & 52,65 \\
III & 5,6 & 65,52 \\
IV & 5,6 & 65,52 \\
\hline
\end{tabular}

Based on Table 3. Electrical energy produced in Talang Banjar Jambi City, the average generated in the first week obtained electrical energy of $50.31 \mathrm{kWh}$, for the second week electrical energy was obtained at $52.65 \mathrm{kWh}$, for the third week obtained electrical 
energy was $65.52 \mathrm{kWh}$, in the fourth week the average electrical energy was $65.52 \mathrm{kWh}$, so that the average electrical energy for four weeks was $58.5 \mathrm{kWh}$.

\section{CONCLUSION}

Based on the research results of Biogas Production and Electrical Energy from Market Waste at Fixed Dome Biodigester in Talang Banjar Jambi, it was found that the methane gas content obtained exceeds $60 \%$ with an average biogas volume of $5 \mathrm{~m} 3 /$ hour, and the electrical energy produced was $58.5 \mathrm{kWh} /$ hour.

\section{AUTHORS' CONTRIBUTIONS}

All autors in this publication have jointly carried out research activities and writing this article.

\section{ACKNOWLEDGMENTS}

This article's research/publication sponsored from DIPA Politeknik Negeri Sriwijaya 2021. We gratefully thank Director, Research Unit and Community service and Renewable Energy Engineering Master's program of Politeknik Negeri Sriwijaya for their strong support of this study

\section{REFERENCES}

[1] Dinas Lingkungan Hidup Kota Jambi, Laporan Status Lingkungan Hidup Kota Jambi, Kota Jambi, 2017.

[2] Ricci M., Confalonieri A., Technical Guidance on the Operation of Organic Waste Treatment Plants, s.1.: International Solid Waste Association, 2016.

[3] Zhang L, Wang C, Energy and GHG analysis of rural household biogas systems in China, vol. 7 no. 2, Energies, 2014, pp. 767-84.
[4] Chen Y, Yang G, Sweeney S, Feng Y, Household biogas use in rural China: A study of opportunities and constraints, vol.14 no.1, Renewable and sustainable energy reviews, 2010, pp. 545-549.

[5] Marchaim U, Biogas process for sustainable development, FAO Corporate Document Repository, 1992.

[6] Bond T, Templeton M R, History and future of domestic biogas plants in the developing world, Energy for Sustainable Development, 2011, pp. $347-354$.

[7] Kalsum L, Hasan A, Rusdianasari, Husaini A, Bow Y, Evaluation of Main Parameter Process of Anaerobic Digestion of Cow Dung in Fixed Dome Biodigester on Methane Gas Quality, vol. 1500 no.1, InJournal of Physics: Conference Series, 2020 .

[8] Artiani G.P, Handayasari, Indah, vol.6 no.2, Jurnal Kilat, 2017, pp. 95-105.

[9] Maryani, Sri, Potensi Campuran Sampah Sayuran dan Kotoran Sapi sebagai Penghasil Biogas, Universitas Islam Negeri Malang, 2016.

[10] Mulyanto S, Zulkifli Z, Milaningrum E, Perbandingan sampah organik rumah tangga dengan sampah organik pasar terhadap kuantitas biogas, vol. 16 no.2, Jurnal Polimesin, 2018, pp. 43-6.

[11] Diener S, Gallardo MA, Lohri CR, Vögeli Y, Zurbrügg C, Anaerobic digestion of biowaste in developing countries, Practical information and case studies report, 2014, pp. 1755-315.

[12] Kementrian Pertanian, Biogas, Jakarta (ID), Kementerian Pertanian,

2006. 